\title{
Increased genetic divergence and reduced genetic variation in populations of the snail Bembicium vittatum in isolated tidal ponds
}

\author{
MICHAEL S. J OHNSON* \& ROBERT BLACK \\ Department of Zoology, University of Western Australia, Nedlands, Western Australia 6907, Australia
}

\begin{abstract}
Populations of the littorine gastropod Bembicium vittatum in 47 isolated tidal ponds were used to test effects of isolation and habitat on genetic divergence. The mean $G_{\mathrm{ST}}$ at 13 polymorphic allozyme loci between pond populations and their adjacent shore sites, separated by surface barriers of 1-100 m, was 0.122 , which is equivalent to subdivision over distances of $4-5 \mathrm{~km}$ among shore sites. At distances up to $15 \mathrm{~km}$, subdivision among pond populations (mean $G_{\mathrm{ST}}=0.181$ ) was substantially greater than among shore sites (mean $G_{\mathrm{ST}}=0.115$ ); beyond $45 \mathrm{~km}$ mean $G_{\text {ST }}$ was 0.342 among ponds, compared with 0.279 among shore sites. Genetic divergence of pond populations from their adjacent shore counterparts was less in those ponds with greater interchange with the ocean. Greater divergence was associated with decreased allozyme variation within the pond populations, which was also lower in smaller ponds with smaller populations. With one exception, allelic frequencies did not differ consistently between ponds and shores or in association with differences in habitat among the ponds. The exception was the consistently higher frequency of Lapl $^{112}$ in pond populations. A mark-recapture experiment failed to detect differential survival or growth of Lap1 genotypes, either within or among ponds and shore sites, leaving open the mechanisms of this apparently adaptive divergence. Overall, the results confirm a substantial increase in genetic divergence associated with the tidal ponds, and favour the interpretation that degree of isolation and population size, rather than localized selection, are the major determinants of the allozyme divergence.
\end{abstract}

Keywords: genetic drift, genetic subdivision, isolated populations, littorine snail, natural selection.

\section{Introduction}

Isolated populations have long been considered to play a central role in evolutionary divergence (Mayr, 1963; Carson \& Templeton, 1984), although the importance of isolation has been questioned (Ehrlich \& Raven, 1969). Introduced species have provided opportunities to examine genetic changes associated with founding and subsequent isolation of populations, but more relevant from an evolutionary perspective are naturally occurring local founder populations and isolates (Eckert et al. 1996). Island populations, for example, are well recognized for their special contribution to evolutionary divergence. In coastal marine species, embayments and estuaries (Burton \& Feldman, 1982; Johnson et al., 1986; Ayvazian et al., 1994), as well as islands (Johnson et

\footnotetext{
*Correspondence. E-mail: msj@cyllene.uwa.edu.au
}

al., 1994; Parsons, 1996), have been shown to favour genetic divergence.

Studies of the intertidal snail Bembicium vittatum (Gastropoda: Littorinidae) have shown the importance of three types of barriers to gene flow in causing high levels of genetic subdivision in the Houtman Abrolhos Islands, Western Australia. First, because this species lacks a planktonic stage (Black et al., 1994), much of its dispersal is by crawling, so that mixing is restricted beyond about $150 \mathrm{~m}$, resulting in patterns of isolation by distance (Johnson \& Black, 1995). Secondly, water gaps of even $500 \mathrm{~m}$ between islands cause a doubling of the level of genetic subdivision, compared with similar distances along continuous shores (Johnson \& Black, 1995). Most dramatically, tidal ponds, separated from adjacent shores by surface barriers of 5-40 m, are also associated with almost a doubling of levels of genetic subdivision, compared with that 
among adjacent shore populations (Johnson \& Black, 1991, 1997).

The tidal ponds, which are apparently sinkholes or dolines in the coral rubble that forms these islands, are unusual habitats that characterize the Houtman Abrolhos Islands (Black \& Johnson, 1997). There are about 60 ponds, ranging from a few square metres to several hectares in area, and from those that are wet only for a few hours on the highest spring tides to those that have permanent water more than $2 \mathrm{~m}$ deep. The ponds have no surface connection with the adjacent ocean, and their subterranean connections vary, as evidenced by the widths of the surface barriers, rates of tidal exchange, and associated faunas (Black \& Johnson, 1997). This diversity offers special opportunities for examining the causes of genetic subdivision. As emphasized by Barton \& Charlesworth (1984), one difficulty in assessing the importance of small, isolated populations is distinguishing between the genetic effects of population bottlenecks and isolation from the direct effects of natural selection. The large number of tidal ponds in the Abrolhos Islands provides an excellent opportunity to separate the influences of isolation and habitat.

In our initial study of allozyme variation in $B$. vittatum, we included eight pond populations, along with adjacent shore populations from throughout the Houtman Abrolhos (Johnson \& Black, 1991). Based on five polymorphic loci, the mean $F_{\mathrm{ST}}$ was 0.277 among the pond populations, compared with 0.152 among their shore counterparts. There was a suggestion that the ponds that were more isolated had genetically more divergent populations, but the small number of sites and the crude indicators of connection left this possibility open. Subsequent study of patterns of genetic variation among shore populations in the Houtman Abrolhos has shown the importance of comprehensive geographical sampling, larger numbers of polymorphic loci, and careful characterization of the habitat (Johnson \& Black, 1996). In the present study, we extend our analysis to variation at 13 polymorphic allozyme loci in populations of B. vittatum from 47 tidal ponds for which we have information on the physical and biological characteristics. With this information, we have tested the importance of connections of the ponds and possible correlates of environmental characteristics in determining the genetic characteristics of these populations. Specifically, we ask: (i) how large is the divergence associated with ponds of varying characteristics? (ii) how significant is this variation compared with divergence among the shore populations? (iii) are divergence and/or isola- tion associated with decreased levels of genetic variation? and (iv) is the genetic divergence associated with the characteristics of the ponds?

\section{Materials and methods}

\section{Samples}

Samples of adult B. vittatum were collected between January 1992 and September 1993 from 47 ponds from throughout the Houtman Abrolhos Islands, spanning distances up to $60 \mathrm{~km}$ (Fig. 1). Parallel samples were collected from adjacent lagoonal shores. Along continuous shores, the genetic neighbourhood spans about $150 \mathrm{~m}$ (Johnson \& Black, 1995). Because some ponds were within $50 \mathrm{~m}$ of each other, some shore sites were paired with more than one pond, rather than replicating shore samples from within a neighbourhood; in total, 28 shore sites were included, each paired with up to four ponds. Samples were generally 48 snails per site, with a range of 46-78.

For each pond, information was recorded to provide indices of isolation from the adjacent shore and of habitat characteristics. Distance to the adjacent shore $(1-100 \mathrm{~m})$, height of the surface barrier (10-300 cm above high water), and distance from the crest of the barrier to the adjacent shore $(0-50 \mathrm{~m})$ were measured. The size of a pond could reflect both the potential for connection to the ocean and the consequences of isolation in terms of population size, so surface area was estimated as the area of an oval, based on measured length and width of the pond, and varied from 16 to $43982 \mathrm{~m}^{2}$. The tidal level of the base of each pond was surveyed $(-1.0-0.9 \mathrm{~m}$, relative to low water datum in adjacent ocean), and maximum depth (0.1-2.2 m), depth at low tide $(0-1.4 \mathrm{~m}$, measured at a tide level of $0.4 \mathrm{~m}$ above low water in the adjacent ocean, during neap tides, in which the tidal range was less than $0.2 \mathrm{~m})$, and tidal range $(0.1-0.8 \mathrm{~m}$, measured during spring tides of $0.8 \mathrm{~m}$ range in adjacent ocean) provided indicators of exchange and retention of water. Presence of fish in the ponds provided a biological indicator of connection.

The physical characteristics of the ponds were described by the base level, depth at $0.4 \mathrm{~m}$ tide, tidal range, log area, slope of the shore and slope of the substrate of B. vittatum (slopes coded as flat, gradual, steep, vertical, undercut). The biological characteristics were described by presence or absence of an algal mat, floating algae, the succulent halophyte Sarcocornia sp. (none, scattered, abundant), mangroves (none, edge only, forming a

(C) The Genetical Society of Great Britain, Heredity, 80, 163-172. 
canopy), fish (present or absent), and abundances of the gastropods B. vittatum, Austrocochlea constricta and Zeacumantus diemenensis (coded as 0, 1-10, 11-50, 51-100, and $>100$ per 10 linear metres of shore). Width and height of the shells of $B$. vittatum were also measured. Shell shape in this species has both genetic and plastic components (Parsons, 1997; authors, unpubl. data). Because the shells of littorines, including B. vittatum (Johnson \& Black, 1996, 1997; Reid, 1996), are highly responsive to environmental conditions, size and shape are useful indices of habitat, whether the variation is genetic or plastic.

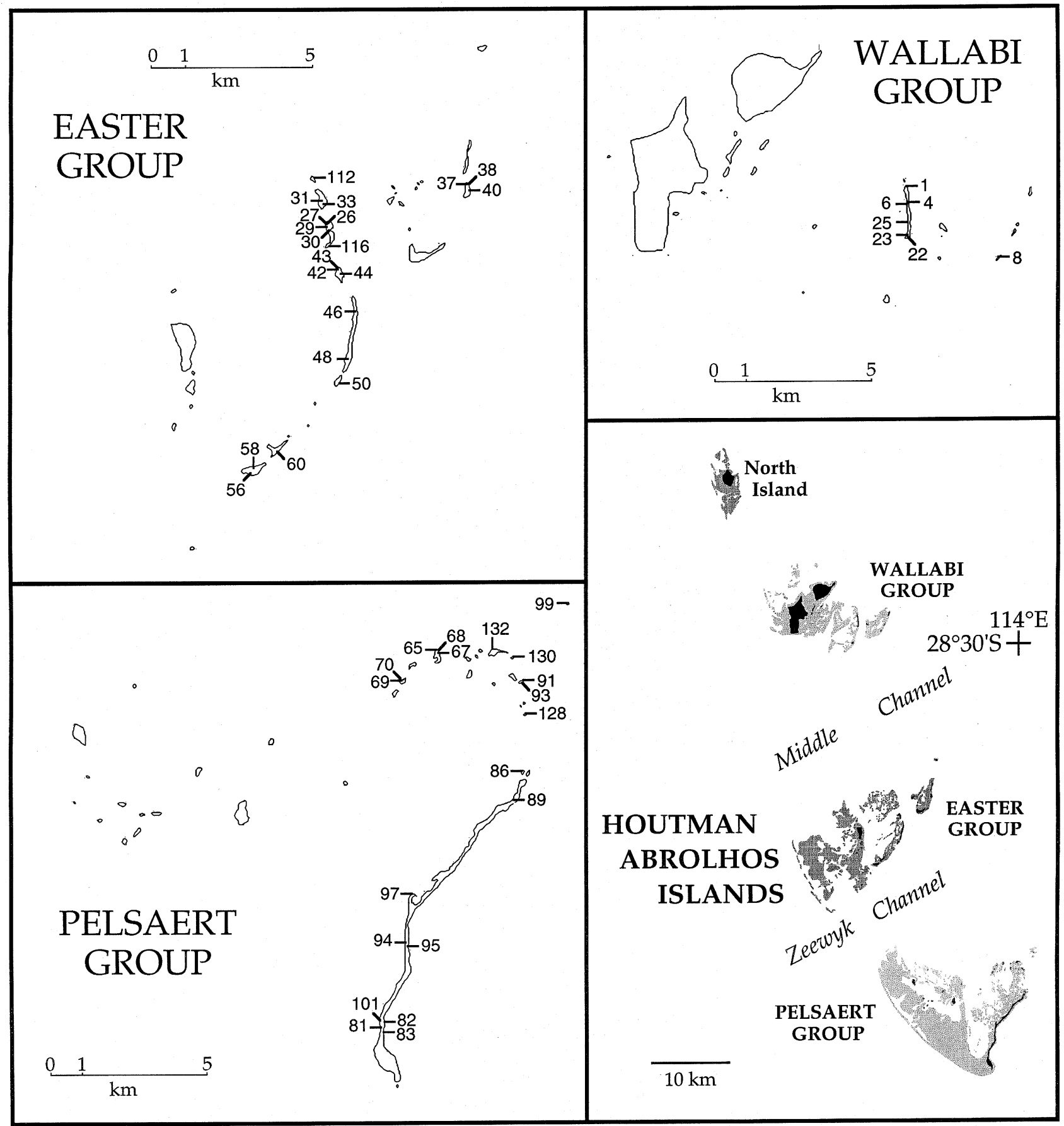

Fig. 1 Maps of the Houtman Abrolhos Islands, showing sampling sites (with code numbers) of Bembicium vittatum from intertidal ponds. On the large-scale map, shading indicates shallow reefs; on the fine-scale maps, only the islands are shown.

(C) The Genetical Society of Great Britain, Heredity, 80, 163-172. 
Mean width of snails $\geq 8 \mathrm{~mm}$ was used as a measure of size in the adult population; in the few populations with no snails this large, the mean of the five largest was used. In species of Bembicium, there is a strong allometric increase of height with increasing width (Reid, 1988). To obtain a measure of shape independent of size, we calculated the regression of logarithm of shell height against logarithm of width within each sample, and then took the mean expected height for a width of $8.5 \mathrm{~mm}$ as the measure of shape in that sample.

\section{Analyses}

Variation was examined at 13 allozyme loci, as described previously (Johnson \& Black, 1996). The enzymes were selected because a preliminary survey had shown them to be polymorphic. For each sample, allelic frequencies at each locus and mean observed heterozygosity, total number of alleles, and proportion of polymorphic loci were estimated. Because of the size of the data set (31 alleles in 75 populations), only summary analyses are presented here; the full set of data is available from the authors.

Divergence between populations was measured by pairwise $G_{\text {ST }}(\mathrm{Nei}, 1973)$, an appropriate measure of genetic distance when the focus is on gene flow and genetic subdivision (Slatkin, 1993). Stepwise multiple regressions against the indices of isolation were used to test for associations of $G_{\text {Sт }}$ and the measures of genetic variability with isolation of each pond population. The overall association of genetic divergence with the ponds was assessed by comparing average values of $G_{\mathrm{ST}}$ among pond populations with those among the corresponding shore populations. The amount and pattern of subdivision were summarized by plotting mean pairwise $G_{\mathrm{ST}}$ against geographical distance. Because the 1081 pairwise values based on 47 sites are not independent, we grouped the values within $1-\mathrm{km}$ intervals, plotting mean values for these groups to give a simple summary of the underlying patterns. Only means based on at least three independent comparisons were included. As a more direct contrast of subdivision associated with ponds as compared with shores, the mean values of pairwise $G_{\mathrm{ST}}$ among ponds (grouped in 1-km intervals) were plotted against the values for the corresponding paired shore populations. Because 11 of the shore sites were paired with more than one pond, some of the comparisons were between a shore sample and itself. For these, we assigned a value of 0.011 for $G_{\mathrm{ST}}$, as this was the mean value that we had found previously for samples within $50 \mathrm{~m}$ in continuous shore populations (Johnson \& Black, 1995).

To test whether genetic divergence was associated with the characteristics of different ponds, allelic frequencies were compared with habitat variables using stepwise multiple regression. A fundamental problem in determining the effects of the ponds is to remove the underlying patterns of geographical variation of the shore populations, as these will have influenced the history of the pond populations. A study of 81 shore sites showed that there are geographically coherent patterns of divergence between the three main island groups (Fig. 1), among subgroups within these groups, and in the form of isolation by distance within subgroups (Johnson \& Black, 1996). To control for this geographical variation, we included the frequency of an allele in the adjacent shore sample as an independent variable in the regressions, which then showed whether the habitat variables explained the residual variation in allelic frequencies. For each allele, we excluded sites at which neither the pond nor the shore samples had the allele, so that the analyses were based only on sites with the potential for variation in allelic frequencies.

These contrasts between pond and shore populations and among pond populations were made for 31 alleles at 13 loci. The sequential Bonferroni procedure (Rice, 1989) was used to correct for possibly spurious significant tests. The Bonferroni procedure adjusts $\alpha$ by dividing by the number of separate tests. Considering the 31 alleles to represent separate tests would give an excessive compensation, because alleles at a locus are not completely independent (for two alleles at a locus, they are identical). For that reason, we used the number of alleles minus the number of loci, or 18 , as the correction factor.

\section{Selection experiment}

A mark-recapture and translocation experiment was conducted to test for possible selection at the Lap1 locus, which was found to be associated with the tidal ponds. In September 1995, a large sample of small snails was collected from pond 112, in the Easter Group (Fig. 1), and sorted into $0.5 \mathrm{~mm}$ size classes by sieving; only those with sieve diameters of $2-5 \mathrm{~mm}$ were included in the experiment. Four groups of 848 snails each, and with identical sizefrequency distributions, were marked by spray-painting the entire dorsal surface with enamel paint (Taubman's Fiddly Bits). The marked snails were released in two ponds and at two shore sites 
(frequency of Lap1 $1^{112}$ in adults in brackets): pond $112(0.44)$, the native site; shore $113(0.11)$, which is adjacent to pond 112; pond 101 (0), on Pelsaert Island (Fig. 1); shore 85 (0), which is adjacent to ponds 94 and 95, also on Pelsaert Island. A control sample of 424 snails with the same size distribution was frozen for subsequent electrophoresis. Marked snails were harvested in February 1996.

Possible selective mortality was tested by comparisons of allelic frequencies in the surviving snails among release sites and between the survivors and the initial control sample. Contingency tests of variation in allelic frequencies were carried out by randomization, using CATSTAT (B. Engels, University of Wisconsin). Possible selection, acting through growth rates, was also tested. The paint marks showed the initial sizes of the recaptured snails, allowing measurement of the increase in shell width over the 5-month period. Because larger snails grew less, growth was regressed against initial width within each of the four experimental groups. At each site, the growth of each snail was adjusted to its expected growth at initial width of $4 \mathrm{~mm}$, based on its residual from the regression line. These adjusted values were then compared among Lap1 genotypes.

\section{Results}

\section{Genetic subdivision}

Among all sites, mean $G_{\mathrm{ST}}$ among ponds was 0.263 , compared with 0.187 for the shore sites. The increase in subdivision associated with the ponds was greater at smaller geographical distances than at larger ones (Fig. 2, Table 1). Within island groups (distances $<15 \mathrm{~km}$ in Fig. 2), the mean $G_{\mathrm{ST}}$ among ponds was 57 per cent greater than that among shore sites, whereas the difference was only 23 per cent for comparisons between the southern and northern island groups (45-60 km apart). Both sets of comparisons showed an overall increase of $G_{\mathrm{ST}}$ with distance. The effect of the ponds superimposed on this underlying geographical pattern is seen clearly in the regression of mean $G_{\mathrm{ST}}$ for the ponds against that for the shore sites, both grouped in 1-km intervals (Fig. 3). The basic association with distance is reflected in the $r^{2}$ of 0.417 for the 36 $1-\mathrm{km}$ intervals represented by both pond and shore comparisons. However, at all but three of the $1-\mathrm{km}$ intervals, $G_{\mathrm{ST}}$ was greater for the ponds than the shore sites.

Comparisons between ponds and their adjacent shore sites, which are separated by 4-100 m, gave a mean $G_{\mathrm{ST}}$ of 0.122 , which would correspond with the values at distances of $4-5 \mathrm{~km}$ in comparisons among shore sites (Fig. 2). However, there was a wide range, $0.006-0.363$, in $G_{\mathrm{ST}}$ between ponds and their adjacent shores. A stepwise multiple regression of these values against the set of isolation variables for the 47 ponds showed a significant negative association with the presence of fish $\left(r^{2}=0.121, P<0.05\right)$, but not with tidal characteristics or distance from shore. Because presence or absence of fish is a dichotomous trait, a more appropriate test of this association is to compare means of those ponds with or without fish. The mean $( \pm \mathrm{SE}) G_{\mathrm{ST}}$ of the 36
Fig. 2 Relationship of mean $( \pm S E)$ pairwise $G_{\text {ST }}$ with distance, grouped in 1-km intervals, for Bembicium vittatum. The comparisons between ponds and shore are for adjacent pairs only; all other comparisons are either between ponds or between shore sites. Values based on fewer than three independent comparisons are excluded.

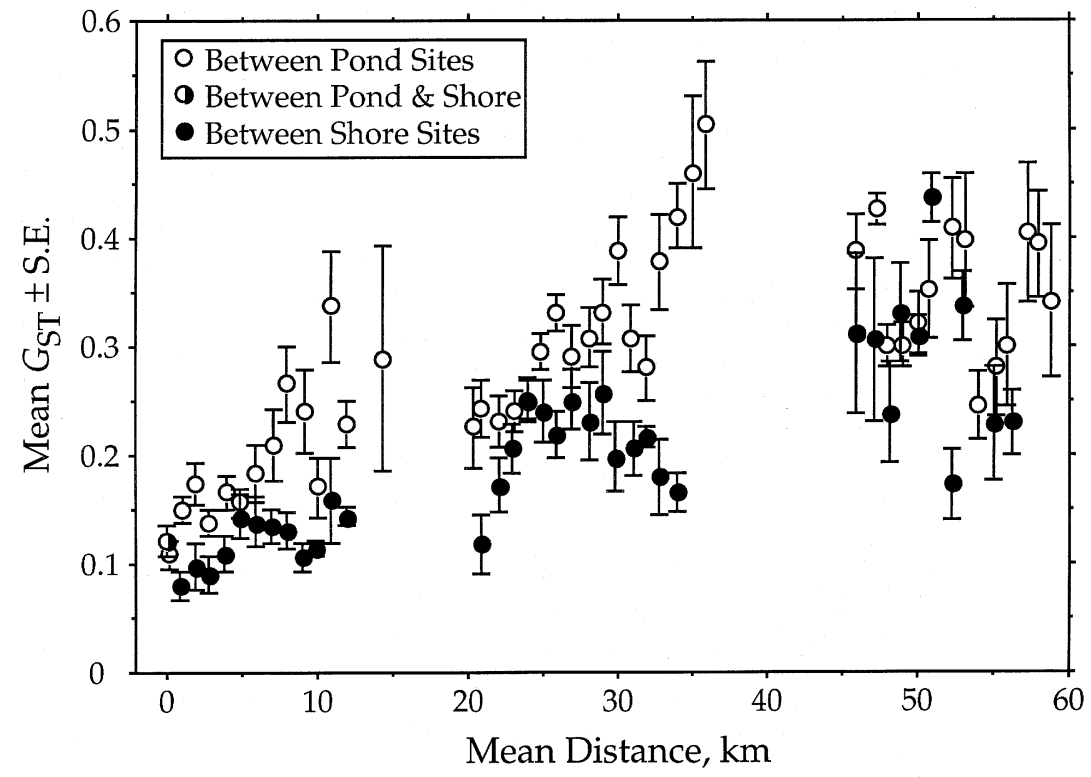


Table 1 Mean pairwise $G_{\mathrm{ST}}$ in comparisons among pond and among shore populations of Bembicium vittatum within and between island groups

\begin{tabular}{lccc}
\hline Comparisons & \multicolumn{3}{c}{ Among } \\
& $\mathrm{km}$ & $\begin{array}{c}\text { Among shore } \\
\text { ponds }\end{array}$ & sites \\
\hline Within groups & \multicolumn{1}{c}{$<15$} & 0.181 & 0.115 \\
Between adjacent groups & $20-36$ & 0.304 & 0.216 \\
Between distant groups & $45-60$ & 0.342 & 0.279 \\
All comparisons & $0-60$ & 0.263 & 0.187 \\
\hline
\end{tabular}

populations in ponds without fish was $0.139 \pm 0.016$, more than twice as large as the value of $0.061 \pm 0.019$ for the 11 ponds with fish, indicating that, on average, substantial connection (as evidenced by the presence of fish) decreases genetic subdivision.

The importance of isolation is also evident in comparisons of levels of genetic variation in the pond populations. Among the 47 ponds, greater genetic divergence from their shore counterparts, as measured by $G_{\mathrm{ST}}$, was associated with fewer alleles per locus $(r=-0.390, P=0.007)$ and lower proportions of polymorphic loci $(r=-0.339, P=0.020)$ in

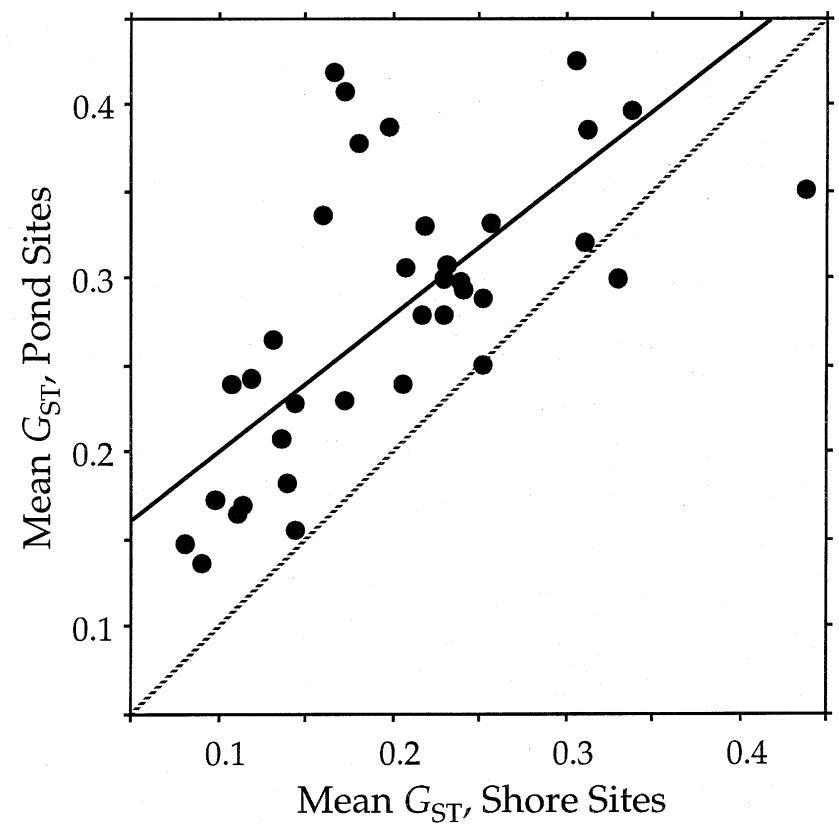

Fig. 3 Comparison for Bembicium vittatum of mean $G_{\mathrm{ST}}$ among ponds and among shore sites within 36 corresponding 1-km intervals. Solid line indicates the Model II regression $(y=0.075+1.142 x)$; dotted line indicates equal values for ponds and shore. The elevations, but not the slopes, of the two lines differ significantly. the ponds; heterozygosity was also negatively correlated with $G_{\mathrm{ST}}$, but not significantly $(r=-0.253$, $P=0.085)$. Stepwise multiple regressions of these measures of variability against the set of isolation variables, $G_{\mathrm{ST}}$ and density of the population of $B$. vittatum revealed an additional set of associations. Both heterozygosity and the number of alleles were primarily associated with $\log$ area $\left(r^{2}=0.099\right.$ and 0.205 , respectively). In addition, heterozygosity was associated positively with population density (multiple $r^{2}=0.189$ ), whereas tidal range contributed positively and $G_{\mathrm{ST}}$ negatively to the regression of total number of alleles, giving a multiple $r^{2}$ of 0.382 . The proportion of polymorphic loci was associated primarily with population density $\left(r^{2}=0.161\right)$, but also associated negatively with $G_{\mathrm{ST}}$ and distance between the crest of the barrier to the shore (multiple $r^{2}=0.333$ ). Thus, reduced genetic variation within the ponds was associated broadly with isolation, smaller populations and greater genetic divergence.

\section{Associations with habitat}

To test for possible consistent genetic differences between pond populations and their shore counterparts, we determined the difference in frequency of each allele between each pond and its paired shore site. Using only those sites where either the pond or the shore (or both) had a particular allele, the mean difference was tested for departure from zero, using a $t$-test. Using the sequential Bonferroni procedure, only the Lap1 $1^{112}$ allele showed an overall consistent association with pond populations. Among 28 pairwise comparisons, the pond population had a higher frequency of Lap1 $1^{112}$ in 22 cases. Although increases were greatest in the Easter Group, the trend was consistent among the three groups of islands: two of three comparisons in the Wallabi Group, 12 of 15 in the Easter Group, and eight of 10 in the Pelsaert Group (Fig. 4). The reversed directions in six cases were all small and nonsignificant. The mean $( \pm S E)$ increase in the frequency of $L a p 1^{112}$ from shore to pond was $0.094 \pm 0.023\left(t_{28}=4.076\right.$, raw $\left.P=0.0004\right)$. With this exception of the Lap1 locus, however, differences between pond and shore populations showed no consistent trends. Thus, although the pond populations differed from their shore counterparts, they did so in different ways.

The variation of allelic frequencies among pond populations reflected strongly the geographical variation among the shore populations. In the broad survey of shore populations (Johnson \& Black, 1996), seven loci (Apk1, Est4, Got1, Lap1, Lpp, Vlp1, 
Fig. 4 Frequencies of the Lap1 $1^{112}$ allele in 47 pond populations (open circles) and 28 shore populations (filled circles) of Bembicium vittatum, plotted against distance north of the southern tip of the Houtman Abrolhos Islands.

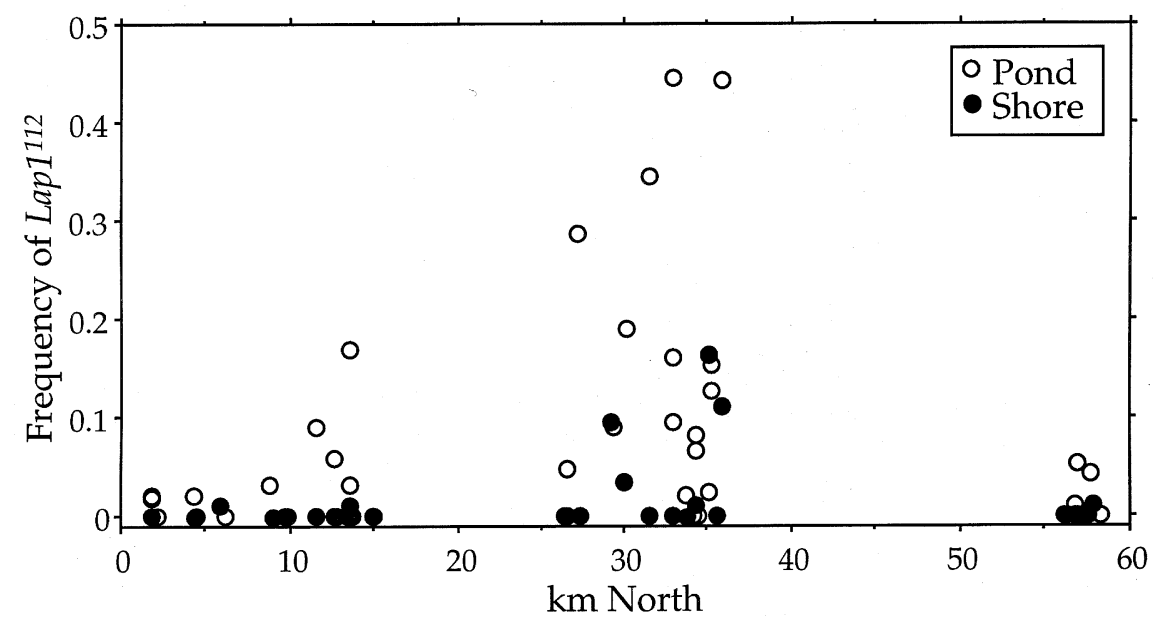

Vlp2) were sufficiently polymorphic to allow legitimate contingency tests of variation among sites. Comparisons of the frequencies of the most common allele between pond populations and their paired shore sites at each of these loci gave highly significant Pearson correlations of $0.400-0.727$, highlighting the need to control for the influence of geographical variation among the shore populations in the tests of association of allelic frequencies with habitat.

Those tests were made by stepwise multiple regression of allelic frequency against the habitat variables, in which the frequency in the paired shore populations was included with the habitat variables. Only those sites where an allele was present in either the pond or the shore population were included. Based on the raw probabilities, only four alleles showed significant associations with variables other than the allelic frequency in the paired shore site. However, none of these four was significant when the Bonferroni correction was applied. Thus, with the exception of the consistently higher frequency of the Lap1 $1^{112}$ allele in the ponds compared with shore sites, there was no evidence of allozymic divergence of pond populations in response to the variation in habitats. Even for Lap $^{112}$ there was no association of allelic frequencies with habitat among the ponds.

\section{Selection experiment}

There were large differences in recapture rates, from 12 per cent at the two shore sites to 47 per cent at pond 101 (Table 2). To the extent that these reflected differences in survival rates, the experimental populations had different potentials for selective mortality among Lap1 genotypes. However, the apparently higher mortality at the shore sites was not associated with change in allelic frequencies. Among all four experimental populations, the frequency of $L_{a p 1^{112}}$ varied only from 0.30 to 0.33 (Table 2). Contingency tests showed no differences among the four populations $(P>0.90)$. In addition, none of the experimental populations differed significantly from the control sample, in which Lap1 ${ }^{112}$ was at a frequency of 0.27 , significantly lower than

Table 2 Summary of results from mark-recapture and translocation of Bembicium vittatum from pond 112. Growth increments are adjusted to initial width of $4 \mathrm{~mm}$, and are shown for the three Lap1 genotypes

\begin{tabular}{|c|c|c|c|c|c|c|}
\hline \multirow[b]{2}{*}{ Release site } & \multicolumn{2}{|c|}{ Recaptures } & \multirow{2}{*}{$\begin{array}{c}\text { Frequency } \\
\text { of } \\
\text { Lap1 }^{112} \pm \mathrm{SE}\end{array}$} & \multicolumn{3}{|c|}{ Mean growth $\pm \mathrm{SE}(\mathrm{mm})$} \\
\hline & $n$ & $\%$ & & $112 / 112$ & $112 / 100$ & $100 / 100$ \\
\hline Pond & 187 & 22.1 & $0.322 \pm 0.025$ & $1.36 \pm 0.10$ & 0.11 & 1.17 \\
\hline Pond 101 & 398 & 46.9 & $0.323 \pm 0.036$ & $0.98 \pm 0.03$ & $1.01 \pm 0.05$ & $0.98 \pm 0.02$ \\
\hline Shore 113 & 99 & 11.7 & 0.034 & $4.12 \pm 0.15$ & $4.40 \pm 0.14$ & $4.14 \pm 0.11$ \\
\hline Shore 85 & 99 & 11.7 & $0.297 \pm 0.018$ & $5.76 \pm 0.24$ & $5.71 \pm 0.25$ & $5.76 \pm 0.14$ \\
\hline
\end{tabular}


the value of 0.44 in the adults in the source population.

Growth rates differed substantially among sites, in the opposite direction to recapture rates. Converted to average growth for snails of $4 \mathrm{~mm}$ initial width, the average increase in width was only 1.1 and $1.2 \mathrm{~mm}$ in ponds 101 and 112, respectively, compared with 4.3 and $5.9 \mathrm{~mm}$ at shore sites 113 and 85 . Within each of these groups, however, no differences in growth rates were detected among Lap1 genotypes (Table 2).

\section{Discussion}

The central result of this study is that the tidal ponds are associated with substantial local increases in genetic divergence of $B$. vittatum. This divergence is not only between pond populations and the adjacent shore populations, but also among the ponds. At distances up to $15 \mathrm{~km}$, the mean pairwise $G_{\mathrm{ST}}$ of 0.181 among ponds is 57 per cent greater than that among shore populations; even at distances of $45-60 \mathrm{~km}$ the increase is 23 per cent. This result confirms earlier evidence for isolation of the pond populations (Johnson \& Black, 1991). The larger number of sites and polymorphic loci in the present study allow us to examine the nature of that divergence.

The significantly lower $G_{\mathrm{ST}}$ between adjacent shore sites and ponds that have fish fits with the expectation that populations in ponds with greater connection to the ocean are less isolated. However, that relationship is not a simple one. Even when presence or absence of fish was removed as a variable, the physical indicators of isolation were not significantly associated with levels of divergence between paired ponds and shores. Part of the difficulty is that the connections between ponds and the ocean are complex and heterogeneous; for example, in a detailed study of six ponds, it was found that the tidal range in one pond $40 \mathrm{~m}$ from the shore followed closely that of the ocean, indicating relatively free subterranean connection, whereas another pond only $8 \mathrm{~m}$ from the shore showed a highly dampened tidal range, indicating less connection (Black \& Johnson, 1997). In addition, different types of connections may be important for B. vittatum in different ponds; for example, occasional storm surges over narrow, low barriers may transport snails to some ponds, whereas occasional movements through subterranean channels may be more important in others. Furthermore, we cannot distinguish among possible founder effects associated with colonization of a pond, subsequent bottlenecks, and the effectiveness of barriers preventing occasional gene flow. Indeed, the presence of fish in a pond, although requiring some degree of connection to the ocean, also requires sufficient volume and persistence of water, which could, in turn, reflect less likely bottlenecks for B. vittatum. Thus, we can conclude only that the association of lower levels of genetic divergence with this complex biological indicator indicates variation in the effects of isolation among pond populations.

Whatever the exact conditions favouring greater divergence are, which probably differ among ponds, the divergence of these isolated populations is associated with reduced genetic variability. In addition to the negative associations of number of alleles and proportion of polymorphic loci with $G_{\mathrm{ST}}$, the measures of variability were higher in larger ponds with denser populations of B. vittatum. Thus, it appears that larger, and probably more stable, populations are less affected by isolation. These relationships were not strong, however, emphasizing the need for large numbers of polymorphic loci and large numbers of sites with different characteristics in order to detect underlying patterns of divergence and genetic variability. The patterns were clearer for number of alleles and proportion of polymorphic loci than for average heterozygosity. This lower sensitivity of heterozygosity as a measure of variability is consistent both with theoretical expectations (Nei et al., 1975) and with comparisons among experimental isolated populations (Leberg, 1992). The decrease in polymorphism in these isolated, genetically divergent populations of $B$. vittatum is similar to that found in well-documented sequences of colonizing populations (Johnson, 1988; Stone \& Sunnuchs, 1993), and favours the view that the allozyme divergence has been determined more by random drift than by adaptations to particular habitats.

Our search for genetic associations with the extensive habitat variation among the ponds supports this interpretation. With the exception of the generally higher frequencies of Lap1 ${ }^{112}$ in the tidal ponds than in the shore populations, we found no evidence of allozymes varying in response to habitat. Although selection by some subtle, unmeasured agent cannot be excluded, the apparent independence of the allozyme divergence from environmental conditions is consistent with comparisons among 81 shore populations of B. vittatum, which showed that probable patterns of gene flow, rather than habitat, determined the major patterns of allozyme variation in the Abrolhos Islands (Johnson \& Black, 1996). Thus, it appears that, at least in cases of extreme 
subdivision of populations, chance, associated with degree of isolation and population bottlenecks, is the important determinant of allozyme frequencies, so that patterns of allozyme divergence reflect history and population structure, rather than localized effects of selection.

The association of $\operatorname{Lap1}^{112}$ with tidal ponds is a striking exception. This allele is rare in shore populations, but is found in most of the tidal ponds. This association was first suggested for ponds in the Easter Group, where the frequency of $\operatorname{Lap}^{112}$ is highest (Johnson \& Black, 1991). The present results confirm its generality; not only does this otherwise rare allele occur at moderate frequencies in most ponds in the Easter Group, but it occurs at low frequencies in ponds in the Wallabi and Pelsaert Groups, where it is extremely rare in the shore populations (Fig. 4). Similarly exceptional associations of allelic frequencies with habitat have been found in two other littorines, Littorina saxatilis and L. mariae, in which most allozyme loci vary independently of habitat, but one locus shows strong, consistent associations with habitat (Johannesson \& Johannesson, 1989; Tatarenkov \& Johannesson, 1994). In each case, the repeatability of the associations in different places is difficult to explain other than in terms of habitat-related selection. In each case, however, the nature of that selection remains obscure.

The mark-recapture and translocation experiment with $B$. vittatum failed to give any evidence of differential mortality or growth rates of Lap1 genotypes, either within or between pond and shore sites. However, temporal variation was shown by the lower frequency of $\operatorname{Lapl}^{112}$ in young snails in 1995 than in adults in 1993 (0.27 compared with 0.44). This suggests that selection may operate sporadically, under special conditions. The fact that ponds of very different characteristics share the higher frequencies of Lap $^{112}$ further suggests that the selective agent must be something that is likely to affect all ponds in contrast with adjacent shores. One possibility is occasional decreases in salinity associated with heavy storms; for example, decreases in salinity of 3-7 per cent were found in six ponds of differing characteristics following one heavy storm (Black \& Johnson, 1997). Furthermore, Lap is associated with osmoregulation in molluscs, and the Lap polymorphism in Mytilus edulis has been shown to vary in response to salinity (Hilbish \& Koehn, 1985). Although speculative, this possibility may prove to be a useful avenue for testing the mechanisms underlying the unusual association of Lap $^{112}$ in B. vittatum with the tidal ponds. Regardless of the mechanisms, this apparent example of selection highlights the potential evolutionary importance of these isolated populations.

\section{Acknow ledgements}

We thank John Clarke, skipper of Tako, for transport throughout the Houtman Abrolhos, Kim Brooks, Susie Johnson, Karen Parsons, Jane Prince, Angela Prince, Michelle Stuckey and Kelley Whitaker for help in the field, and Caroline Fuery, Darcy Hebbert, Michelle Stuckey and Rachel Standish for help in the laboratory. The Western Australian Fisheries Department provided accommodation at their field camps. Financial support was provided by the Australian Research Council.

\section{References}

AYVAZIAN, S. G., JOHNSON, M. S. AND McGlASHAN, D. J. 1994. High levels of genetic subdivision of marine and estuarine populations of the estuarine catfish Cnidoglanis macrocephalus (Plotosidae) in southwestern Australia. Mar. Biol., 118, 25-31.

BARTON, N. H. AND CHARLESWORTH, B. 1984. Genetic revolutions, founder effects, and speciation. Ann. Rev. Ecol. Syst., 15, 133-164.

BLACK, R. AND JOHNSON, M. s. 1997. Tidal ponds: unusual habitats characteristic of the Houtman Abrolhos Islands. In: Wells, F. E. (ed.) The Marine Flora and Fauna of the Houtman Abrolhos Islands, Western Australia, pp. 47-61. Western Australian Museum, Perth.

BLACK, R., TURNER, S. AND JOHNSON, M. S. 1994. The early life history of Bembicium vittatum Philippi, 1846. Veliger, 37, 393-399.

BURton, R. S. AND FEldman, M. w. 1982. Population genetics of coastal and estuarine invertebrates: does larval behavior influence population structure? In: Kennedy, V. S. (ed.) Estuarine Comparisons, pp. 537-551. Academic Press, New York.

CARSON, H. L. AND TEMPLETON, A. R. 1984. Genetic revolutions in relation to speciation: the founding of new populations. Ann. Rev. Ecol. Syst., 15, 97-131.

ECKERT, C. G., MANICACCI, D. AND BARRETT, s. C. H. 1996. Genetic drift and founder effect in native versus introduced populations of an invading plant, Lythrum salicaria (Lythraceae). Evolution, 50, 1512-1519.

EHRLICH, P. R. AND RAVEN, P. H. 1969. Differentiation of populations. Science, 188, 221-228.

HILBISH, T. J. AND KOEHN, R. K. 1985. The physiological basis of natural selection at the LAP locus. Evolution, 39, 1302-1317.

JOHANNESSON, K. AND JOHANnesson, B. 1989. Differences in allele frequencies of Aat between high- and mid-rocky shore populations of Littorina saxatilis (Olivi) suggest selection in this enzyme locus. Genet. Res., 54, $7-11$. 
JOHNSON, M. s. 1988. Founder effects and geographic variation in the land snail Theba pisana. Heredity, 61, $133-142$.

JOHNSON, M. S. AND BLACK, R. 1991. Genetic subdivision of the intertidal snail Bembicium vittatum (Gastropoda: Littorinidae) varies with habitat in the Houtman Abrolhos Islands, Western Australia. Heredity, 67, 205-213.

JOHNSON, M. S. AND BLACK, R. 1995. Neighbourhood size and the importance of barriers to gene flow in an intertidal snail. Heredity, 75, 142-154.

JOHNSON, M. S. AND BLACK, R. 1996. Geographic cohesiveness versus associations with habitat: genetic subdivision of Bembicium vittatum Philippi (Gastropoda: Littorinidae) in the Houtman Abrolhos Islands. Biol. J. Linn. Soc., 58, 57-74.

JOHNSON, M. S. AND BLACK, R. 1997. Isolation and genetic subdivision of populations of gastropods in tidal ponds. In: Wells, F. E. (ed.) The Marine Flora and Fauna of the Houtman Abrolhos Islands, Western Australia, pp. 89-99. Western Australian Museum, Perth.

JOHNSON, M. S., CREAGH, s. AND MORAN, M. 1986. Genetic subdivision of stocks of snapper, Chrysophrys unicolor, in Shark Bay, Western Australia. Aust. J. Mar. Freshwat. Res., 37, 337-345.

JOHnSON, M. S., WATTS, R. J. AND BLACK, R. 1994. High levels of genetic subdivision in peripherally isolated populations of the atherinid fish Craterocephalus capreoli in the Houtman Abrolhos Islands, Western Australia. Mar. Biol., 119, 179-184.

LEBERG, P. L. 1992. Effects of population bottlenecks on genetic diversity as measured by allozyme electrophoresis. Evolution, 46, 477-494.
MAYr, E. 1963. Animal Species and Evolution. Belknap Press, Cambridge, MA.

NEI, M. 1973. Analysis of gene diversity in subdivided populations. Proc. Natl. Acad. Sci. U.S.A., 70, 3321-3323.

NeI, M., MARUyAma, T. AND CHAKRABORTy, R. 1975. The bottleneck effect and genetic variability in populations. Evolution, 29, 1-10.

PARSONS, K. E. 1996. The genetic effects of larval dispersal depend on spatial scale and habitat characteristics. Mar. Biol., 126, 403-414.

PARSONS, K. E. 1997. Contrasting patterns of heritable geographic variation in shell morphology and growth potential in the marine gastropod Bembicium vittatum: evidence from field experiments. Evolution, 51, 784-796.

REID, D. G. 1988. The genera Bembicium and Risellopsis (Gastropoda: Littorinidae) in Australia and New Zealand. Records Austral. Mus., 40, 91-150.

REID, D. G. 1996. Systematics and Evolution of Littorina. The Ray Society, London.

RICE, w. R. 1989. Analyzing tables of statistical tests. Evolution, 43, 223-225.

SLATKIN, M. 1993. Isolation by distance in equilibrium and non-equilibrium populations. Evolution, 47, 264-279.

STONE, G. N. AND SunNuCHS, P. 1993. Genetic consequences of an invasion through a patchy environment - the cynipid gallwasp Andricus quercusalicis (Hymenoptera: Cypinidae). Mol. Ecol., 2, 251-268.

TATARENKov, A. AND JOHANNESSON, K. 1994. Habitat related allozyme variation on a microgeographic scale in the marine snail Littorina mariae (Prosobranchia: Littorinacea). Biol. J. Linn. Soc., 53, 105-125. 